\title{
Carbon footprint of crop production in Heilongjiang land reclamation area, China
}

\author{
Tianshu Chu, Lu Yu, Derui Wang, Zengling Yang* \\ (College of Engineering, China Agricultural University, Beijing 100083, China)
}

\begin{abstract}
In the context of global warming, agriculture, as the second-largest source of greenhouse gas emissions after industry, had attracted widespread attention from all walks of life to reduce agricultural emissions. The carbon footprint of the planting production system of the Heilongjiang Land Reclamation Area (HLRA), an important commodity grain base in China, was evaluated and analyzed in this paper. On this basis, this paper sought feasible strategies to reduce carbon emissions from two aspects: agronomic practices and cropping structure adjustment, which were particularly crucial to promote the low-carbon and sustainable development of agriculture in HLRA. Therefore, using the accounting methods in IPCC and Low Carbon Development and Guidelines for the Preparation of Provincial Greenhouse Gas Inventories compiled by the Chinese government, relevant data were collected from 2000 to 2017 in HLRA and accounted for the carbon emissions of the planting production system in four aspects: carbon emissions from agricultural inputs, $\mathrm{N}_{2} \mathrm{O}$ emissions from managed soils, $\mathrm{CH}_{4}$ emissions from rice cultivation and straw burning emissions. Then carbon uptake consisted of seeds and straws. Finally, with farmers' incomes were set as the objective function and carbon emissions per unit of gross production value was set as the constraint, this paper simulated and optimized the cropping structure in HLRA. The results showed that there was a "stable-growing-declining" trend in the total carbon emissions and carbon uptake of the planting production system in HLRA, with total carbon emissions of $2.84 \times 10^{10} \mathrm{~kg}$ and total carbon uptake of $7.49 \times 10^{10} \mathrm{~kg}$ in 2017 . In the past 18 years, carbon emissions per unit area and carbon emissions per unit of gross production had both shown a decreasing trend. To achieve further efficiency gains and emission reductions in the planting production system, it was recommended that the local governments strengthen the comprehensive use of straw resources, optimize irrigation and fertilization techniques, and adjust the cropping structure, i.e., increase the planting area of maize and soybeans and reduce the planting area of rice, and increase subsidies to protect the economic returns of planters.
\end{abstract}

Keywords: carbon footprint, carbon emissions, carbon uptake, crop planting structure, Heilongjiang Land Reclamation Area DOI: $10.25165 /$ j.jiabe. 20221501.5588

Citation: Chu T S, Yu L, Wang D R, Yang Z L. Carbon footprint of crop production in Heilongjiang land reclamation area, China. Int J Agric \& Biol Eng, 2022; 15(1): 182-191.

\section{Introduction}

In 2018, the Intergovernmental Panel on Climate Change (IPCC) special report on the impacts of global warming of $1.5^{\circ} \mathrm{C}$ revealed that if global warming continued to increase at the current rate, intensity and frequency of some climate and weather extremes might be higher ${ }^{[1]}$. Reducing greenhouse gas (GHG) emissions is regarded as an effective approach to mitigate the worsening global climate change $\mathrm{e}^{[2-4]}$. Agricultural production releases a large quantity of GHG, which accounts for $52 \%$ and $84 \%$ of global anthropogenic methane and nitrous oxide emissions ${ }^{[5,6]}$. So it is urgent to mitigate GHG emissions in agriculture and promote sustainable development ${ }^{[7]}$.

In China, facing huge population pressure, agricultural outputs must remain increasing to meet food demand, which leads to GHG

\section{Received date: $2019-12-11 \quad$ Accepted date: $2021-12-13$}

Biographies: Tianshu Chu, PhD, Postdoctoral Researcher, research interest: agricultural carbon emissions and reduction, Email: chuts@cau.edu.cn; Lu Yu, MS candidate, research interest: agricultural carbon emissions and reduction, Email: ylgxy@cau.edu.cn; Derui Wang, MS candidate, research interest: agricultural carbon emissions and reduction, Email: 2017505440131@, cau.edu.cn.

*Corresponding author: Zengling Yang, $\mathrm{PhD}$, Professor, research interest: biomass resource utilization. China Agricultural University, Haidian District, Beijing 100083, China. Tel: +86-10-62736778, Email: yangzengling@ cau.edu.cn. emissions increasing ${ }^{[8-10]}$. How to reduce or optimize GHG emissions in agricultural production draws the attention of scientists and policymakers ${ }^{[6]}$. The carbon footprint has been recognized as a good indicator to measure GHG emissions resulting from an organization's activities ${ }^{[11]}$. Besides, this method is widely used to evaluate GHG emissions during crop production and calculate the carbon footprint of crops $^{[12]}$. Recently, many studies have focused on quantifying the carbon footprint of different crops, such as $0.48 \mathrm{~kg} \mathrm{CO}_{2}$-eq $/ \mathrm{kg}$ for maize, $0.75 \mathrm{~kg} \mathrm{CO}$-eq $/ \mathrm{kg}$ for wheat, $1.60 \mathrm{~kg} \mathrm{CO}_{2}$-eq $/ \mathrm{kg}$ for rice $^{[13]}$, and $4.43 \mathrm{~kg} \mathrm{CO}$-eq $/ \mathrm{kg}$ for cotton ${ }^{[14]}$. But these carbon footprints are higher than that in the $\mathrm{USA}^{[15,16]}$, which indicates that managing agricultural practices during crop production will be a solution to reduce GHG emissions.

So more and more attention is paid to develop low-emission technologies at all crop production stages, including soil preparation $^{[17,18]}$, fertilizer application ${ }^{[19-22]}$, irrigation ${ }^{[23,24]}$, crop rotation $^{[25-27]}$, and crop-livestock integrated system ${ }^{[28,29]}$. Firstly, He et al. ${ }^{[17]}$ compared six tillage practices and found that no-tillage $\rightarrow$ subsoil tillage rotation produced the lowest CF in the Loess Plateau of China. At the same time, Lal et al. ${ }^{[18]}$ estimated that no-tillage might be a better choice in the rice-maize system in India. Secondly, Wang et al. ${ }^{[21]}$ found that appropriate fertilizer types, such as ammonium bicarbonate, calcium superphosphate, and potassium chloride, could be beneficial to GHG emissions reduction. And optimizing nitrogen fertilizer inputs ${ }^{[19,22]}$ and 
biochar amendment application ${ }^{[20]}$ might be effective strategies. Thirdly, Yang et al. ${ }^{[27]}$ showed that the carbon footprint of diversified crop rotation systems (sweet potato $\rightarrow$ cotton $\rightarrow$ sweet potato $\rightarrow$ winter wheat $\rightarrow$ summer maize) is lower than the conventional intensive crop production system (winter wheat $\rightarrow$ summer maize) in North China Plain. What's more, maize $\rightarrow$ tomato rotation in India ${ }^{[26]}$ and maize $\rightarrow$ soybean $\rightarrow$ oats rotation in the $\mathrm{USA}^{[25]}$ were also better than the traditional rotation. Besides, irrigated crops produced more grain with a lower carbon footprint ${ }^{[24]}$ so an appropriate irrigation system was chosen for the better environmental benefit ${ }^{[23]}$. Finally, compared with the separated crop production system or separated livestock production system, the crop-livestock integrated system would not only recycle agricultural waste, such as livestock manure and crop residue but also cut down the integrated system GHG emissions ${ }^{[28,29]}$. Most previous studies showed that carbon footprint was an effective indicator to develop cleaner agricultural technologies at the operational level. Meanwhile, improving crop planting structure would be also an important way to reduce GHG emissions ${ }^{[30]}$. At present, researches related to crop planting structure optimization through carbon footprint remain scarce. So this study attempts to use this idea by a case study.

In this research, the carbon footprint was used to estimate carbon emission and carbon uptake of crop production from 2000 to 2017 in the Heilongjiang Land Reclamation Area, China. Besides, in order to mitigate GHG emissions and promote agricultural economic development, a multi-objective optimization model was built to make the adjustments to the crops planting structure in Heilongjiang Land Reclamation Area. Through commutating with farmers, they were willing to plant more soybean due to market requirements, which was also considered in this model.

\section{Materials and methods}

\subsection{Study area}

As China's principal grain production area, Heilongjiang Land Reclamation Area (HLRA) is located in the south of Lesser Hinggan Mountains in northeastern China, including the Songnen Plain and Sanjiang Plain. The Heilongjiang Land Reclamation Administration is located in Harbin. The total land area is 5.54 million $\mathrm{hm}^{2}$. The annual average temperature is $1.7^{\circ} \mathrm{C}-4.8^{\circ} \mathrm{C}$. The annual average rainfall is $430-600 \mathrm{~mm}$, and the frostless season is $110-140 \mathrm{~d}$. The accumulated temperature of $\geq 10^{\circ} \mathrm{C}$ is $2300^{\circ} \mathrm{C}-2700^{\circ} \mathrm{C}$. According to the Statistical Yearbook of Heilongiiang State Farms 2018, the planting area of rice, soybean, maize, potato, wheat, vegetables were $1555363 \mathrm{hm}^{2}, 774023 \mathrm{hm}^{2}$, $445978 \mathrm{hm}^{2}, 18011 \mathrm{hm}^{2}, 17700 \mathrm{hm}^{2}$ and $4354 \mathrm{hm}^{2}$ in 2017. The yield of rice, soybean, maize, potato, wheat, vegetables were 14312061 t, 1893067 t, 4425886 t, 107789 t, 64755 t and $198494 \mathrm{t}$. In brief, rice, soybean and maize are the staple crops, which account for $98.58 \%$ of the total crops planting area.

\subsection{System boundary}

Based on field investigation in HLRA, this study constructed a system boundary and a carbon footprint measurement model of the crop production system in HLRA in order to assess the process of carbon emissions and uptake (Figure 1). The main sources of carbon emissions are 1) Agricultural inputs, including chemical fertilizer, organic fertilizer, agricultural machinery, pesticide, agricultural film, diesel, electricity, labor and seed; 2) $\mathrm{N}_{2} \mathrm{O}$ emissions from managed soils; 3) $\mathrm{CH}_{4}$ emissions from rice cultivation; 4) Straw burning emissions $\left(\mathrm{CO}_{2}\right.$ and $\left.\mathrm{CH}_{4}\right)$. The main sources of carbon uptake are grain and straw.

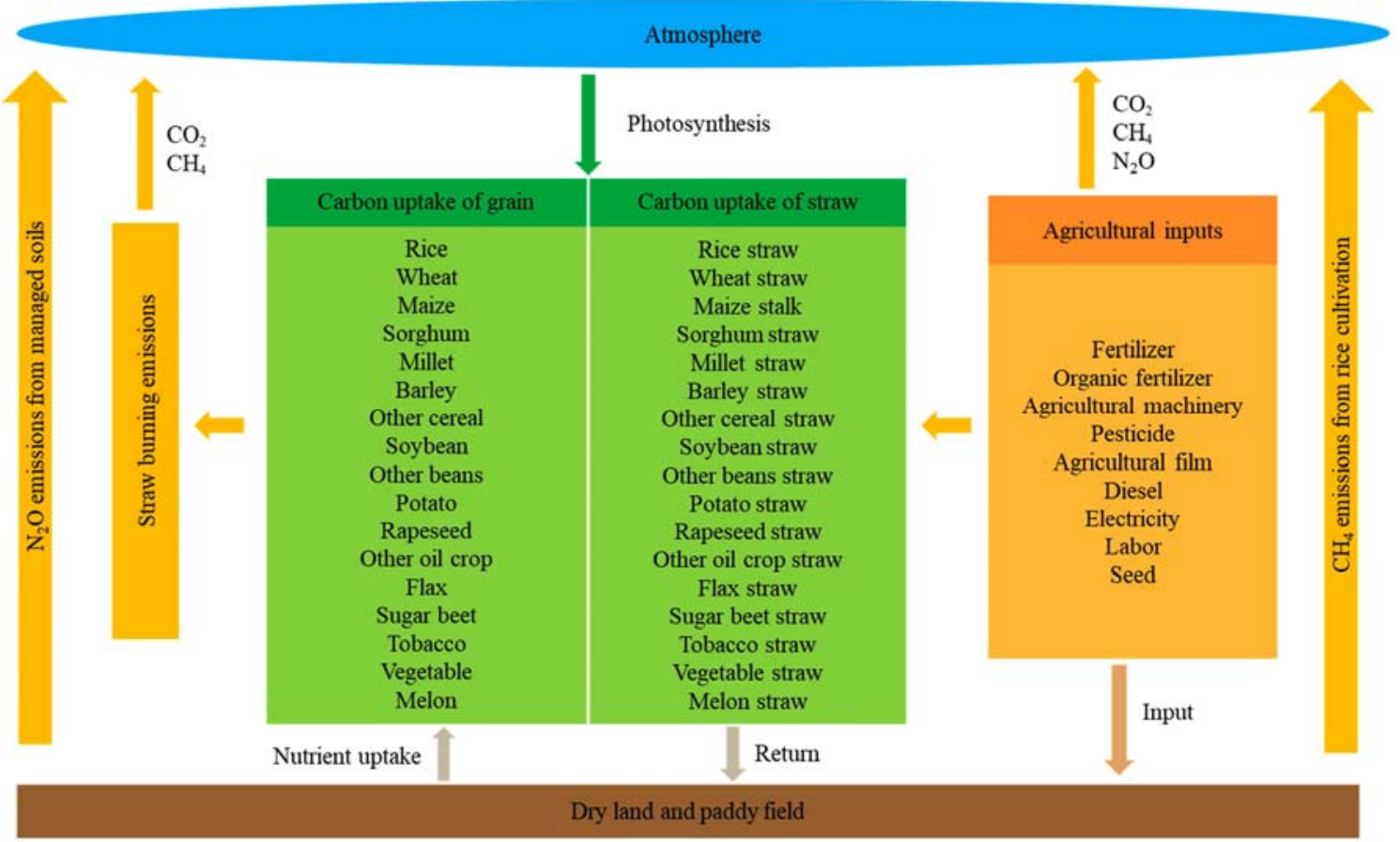

Figure 1 Carbon footprint measurement model of the crop production system

\subsection{Accounting method}

\subsubsection{Data and method references}

Original data of crop production is mainly from the Statistical Yearbook of Heilongjiang State Farms 2001-2018 and field investigation. The carbon footprint method, including factors of agricultural inputs, $\mathrm{N}_{2} \mathrm{O}$ emissions from managed soils, $\mathrm{CH}_{4}$ emissions from rice cultivation and straw burning, refers to Low Carbon Development and Guidelines for the Preparation of Provincial Greenhouse Gas Inventories and the Fifth Assessment Report of IPCC.

2.3.2 Accounting method for carbon emissions

Carbon emissions are calculated by Equation (1). 


$$
\mathrm{CE}=\mathrm{CE}_{\text {input }}+\mathrm{CE}_{\mathrm{N}_{2} \mathrm{O}}+\mathrm{CE}_{\text {paddy-CH }}+\mathrm{CE}_{\text {straw-burning }}
$$

where, $\mathrm{CE}$ is the total carbon emissions from crops production, $\mathrm{kg}$ $\mathrm{CO}_{2}$-eq; $\mathrm{CE}_{\text {input }}$ is agricultural inputs, $\mathrm{kg} \mathrm{CO} \mathrm{CO}_{2}$-eq; $\mathrm{CE}_{\mathrm{N}_{2} \mathrm{O}}$ is $\mathrm{N}_{2} \mathrm{O}$ emissions from managed soils, $\mathrm{kg} \mathrm{CO} \mathrm{CO}_{2}$-eq; $\mathrm{CE}_{\text {paddy-CH4 }}$ is $\mathrm{CH}_{4}$ emissions from rice cultivation, $\mathrm{kg} \mathrm{CO}_{2}$-eq; $\mathrm{CE}_{\text {straw-buring }}$ is straw burning emissions, $\mathrm{kg} \mathrm{CO}_{2}$-eq.

1) Agricultural inputs

Agricultural inputs, including chemical fertilizer, organic fertilizer, agricultural machinery, pesticide, agricultural film, diesel, electricity, labor and seed, are calculated by Equation (2).

$$
\mathrm{CE}_{\text {input }}=\sum \mathrm{AD}_{i} \times \mathrm{EF}_{i}
$$

where, $\mathrm{AD}_{i}$ is agricultural input $i$, data from Statistical Yearbook of Heilongjiang State Farms 2001-2018; $\mathrm{EF}_{i}$ is carbon emission factors, $i=1,2,3, \ldots, n$. The carbon emission factors are listed in Table 1.

\section{Table 1 Carbon emission factors $\left(\mathrm{EF}_{i}\right)$ for crops production} system in HLRA

\begin{tabular}{clc}
\hline$i$ & \multicolumn{1}{c}{ Input } & $\mathrm{EF}_{i}$ \\
\hline 1 & Nitrogenous fertilizer $/ \mathrm{kg} \cdot \mathrm{CO}_{2}$-eq $\cdot \mathrm{kg}^{-1}$ & $7.76^{[31]}$ \\
2 & Phosphate fertilizer $/ \mathrm{kg} \cdot \mathrm{CO}_{2}$-eq $\cdot \mathrm{kg}^{-1}$ & $2.33^{[32]}$ \\
3 & Potassium fertilizer $/ \mathrm{kg} \cdot \mathrm{CO}_{2}-\mathrm{eq} \cdot \mathrm{kg}^{-1}$ & $0.66^{[32]}$ \\
4 & Compound fertilizer $/ \mathrm{kg} \cdot \mathrm{CO}_{2}$-eq $\cdot \mathrm{kg}^{-1}$ & $2.31^{[33]}$ \\
5 & Organic fertilizer $/ \mathrm{kg} \cdot \mathrm{CO}_{2}$-eq $\cdot \mathrm{kg}^{-1}$ & $0.11^{[34]}$ \\
6 & Agricultural machinery $/ \mathrm{kg} \cdot \mathrm{CO}_{2}$-eq $\cdot \mathrm{kg}^{-1}$ & $14.41^{\mathrm{a}}(10.23)^{[35]}$ \\
7 & Pesticide $/ \mathrm{kg} \cdot \mathrm{CO}_{2}$-eq $\cdot \mathrm{kg}^{-1}$ & $16.52^{[36]}$ \\
8 & Agricultural film $/ \mathrm{kg} \cdot \mathrm{CO}_{2}$-eq $\cdot \mathrm{kg}^{-1}$ & $9.44^{[37]}$ \\
9 & Diesel $/ \mathrm{kg} \cdot \mathrm{CO}_{2}$-eq $\cdot \mathrm{kg}{ }^{-1}$ & $3.75^{[38]}$ \\
10 & Electricity $/ \mathrm{kg} \cdot \mathrm{CO}_{2}-\mathrm{eq} \cdot(\mathrm{kW} \cdot \mathrm{h})^{-1}$ & $1.37^{[39]}$ \\
11 & Labor $/ \mathrm{kg} \cdot \mathrm{CO}_{2}-\mathrm{eq} \cdot \mathrm{h}^{-1}$ & $0.07^{[40]}$ \\
\hline
\end{tabular}

Notes: Agricultural machinery is divided into agricultural machinery with power sources (such as tractors, harvest machinery and so on) and supporting agricultural machinery (such as plow and seeder and so on). Data with superscripts "a" is the carbon emission factor of agricultural machinery with power sources; data in the brackets is the carbon emission factor of supporting agricultural machinery. Carbon emission factors of different seeds are from related researches [7,41-44].

2) $\mathrm{N}_{2} \mathrm{O}$ emissions from managed soils

$\mathrm{N}_{2} \mathrm{O}$ emissions from managed soils are calculated by Equation (3).

$$
\mathrm{CE}_{\mathrm{N}_{2} \mathrm{O}}=\mathrm{DE}_{\mathrm{N}_{2} \mathrm{O}}+\mathrm{IE}_{\mathrm{N}_{2} \mathrm{O}}
$$

where, $\mathrm{DE}_{\mathrm{N}_{2} \mathrm{O}}$ is direct $\mathrm{N}_{2} \mathrm{O}$ emissions, $\mathrm{kg} \mathrm{CO} \mathrm{CO}_{2}$-eq; $\mathrm{IE}_{\mathrm{N}_{2} \mathrm{O}}$ is indirect $\mathrm{N}_{2} \mathrm{O}$ emissions, $\mathrm{kg} \mathrm{CO}_{2}$-eq.

And direct $\mathrm{N}_{2} \mathrm{O}$ emissions are calculated by Equation (4).

$$
\mathrm{DE}_{\mathrm{N}_{2} \mathrm{O}}=\mathrm{DE}_{\mathrm{N}_{2} \mathrm{O}-\mathrm{SN}}+\mathrm{DE}_{\mathrm{N}_{2} \mathrm{O}-\mathrm{ON}}+\mathrm{DE}_{\mathrm{N}_{2} \mathrm{O}-\mathrm{CR}}
$$

where, $\mathrm{DE}_{\mathrm{N}_{2} \mathrm{O}-\mathrm{SN}}$ is $\mathrm{N}_{2} \mathrm{O}$ emissions from $\mathrm{N}$ input of fertilizer, including nitrogenous fertilizer and compound fertilizer, $\mathrm{kg} \mathrm{CO}_{2}$-eq; $\mathrm{DE}_{\mathrm{N}_{2} \mathrm{O}-\mathrm{ON}}$ is $\mathrm{N}_{2} \mathrm{O}$ emissions from $\mathrm{N}$ input of organic fertilizer, $\mathrm{kg}$ $\mathrm{CO}_{2}$-eq; $\mathrm{DE}_{\mathrm{N}_{2} \mathrm{O} \text {-CR }}$ is $\mathrm{N}_{2} \mathrm{O}$ emissions from $\mathrm{N}$ input of crop straw, $\mathrm{kg} \mathrm{CO}$-eq.

$\mathrm{N}_{2} \mathrm{O}$ emissions from $\mathrm{N}$ input of chemical fertilizer are calculated by Equation (5).

$$
\mathrm{DE}_{\mathrm{N}_{2} \mathrm{O}-\mathrm{SN}}=\left(\mathrm{AD}_{\mathrm{NF}}+\mathrm{AD}_{\mathrm{CF}} \times \mathrm{TN}_{\mathrm{CF}}\right) \times \mathrm{EF}_{12} \times 44 / 28 \times 265
$$

where, $\mathrm{AD}_{\mathrm{NF}}$ is nitrogenous fertilizer input, $\mathrm{kg} ; \mathrm{AD}_{\mathrm{CF}}$ is compound fertilizer input, $\mathrm{kg} ; \mathrm{TN}_{\mathrm{CF}}$ is $\mathrm{N}$ content of compound fertilizer, $28.41^{[45]} ; \mathrm{EF}_{12}$ is emission factor for direct $\mathrm{N}_{2} \mathrm{O}$ emissions, $0.01 \mathrm{~kg} \mathrm{~N} / \mathrm{kg}^{[46]} ; 44 / 28$ is the conversion coefficient between $\mathrm{N}$ and $\mathrm{N}_{2} \mathrm{O} ; 265$ is $\mathrm{N}_{2} \mathrm{O}$ 100-year Global Warming Potential from the Fifth Assessment Report of IPCC.
$\mathrm{N}_{2} \mathrm{O}$ emissions from $\mathrm{N}$ input of organic fertilizer are calculated by Equation (6).

$$
\mathrm{DE}_{\mathrm{N}_{2} \mathrm{O}-\mathrm{ON}}=\mathrm{AD}_{\mathrm{ON}} \times \mathrm{TN}_{\mathrm{ON}} \times \mathrm{EF}_{12} \times 44 / 28 \times 265
$$

where $\mathrm{AD}_{\mathrm{ON}}$ is organic fertilizer input, $\mathrm{kg} ; \mathrm{TN}_{\mathrm{ON}}$ is $\mathrm{N}$ content of organic fertilizer, $1.78 \%$.

$\mathrm{N}_{2} \mathrm{O}$ emissions from $\mathrm{N}$ input of crop straw returning are calculated by Equation (7).

$$
\begin{aligned}
\mathrm{DE}_{\mathrm{N}_{2} \mathrm{O}-\mathrm{CR}}= & {\left[\sum_{j=1}^{n}\left(Y_{\mathrm{g}, j} \times \mathrm{R}_{\mathrm{S} / \mathrm{G}, j} \times \mathrm{TN}_{\mathrm{S}, j} \times S_{\mathrm{R}}\right)+\sum_{i=1}^{n}\left(Y_{\mathrm{g}, j}+Y_{\mathrm{g}, j} \times \mathrm{R}_{\mathrm{S} / \mathrm{G}, j}\right)\right.} \\
& \left.\times \mathrm{R}_{\mathrm{R} / \mathrm{S}, j} \times \mathrm{TN}_{\mathrm{R}, j}\right] \times \mathrm{EF}_{12} \times \frac{44}{28} \times 265
\end{aligned}
$$

where, $Y_{\mathrm{g}, j}$ is the grain yield of crop $j, \mathrm{~kg} ; \mathrm{R}_{\mathrm{S} / \mathrm{G}, j}$ is straw/grain of crop $j, \%^{[47,48]} ; S_{\mathrm{R}}$ is straw returning rate, $\%$. According to official survey data by HLRA, the ratio of straw returning was 54\% from 1999 to 2008 , and it was $63 \%$ from 2009 to 2017 . $R_{R / S, j}$ is root/shoot of crop $j, \%{ }^{[49]} ; \mathrm{TN}_{\mathrm{S}, j}$ is $\mathrm{N}$ content of straw $j, \%{ }^{[47]}$; $\mathrm{TN}_{\mathrm{R}, j}$ is $\mathrm{N}$ content of $\operatorname{root} j, \%^{[49]}, j=1,2,3, \ldots, n$.

Indirect $\mathrm{N}_{2} \mathrm{O}$ emissions are calculated by Equation (8).

$$
\mathrm{IE}_{\mathrm{N}_{2} \mathrm{O}}=\mathrm{IE}_{\mathrm{N}_{2} \mathrm{O}-\mathrm{ATD}}+\mathrm{IE}_{\mathrm{N}_{2} \mathrm{O}-\mathrm{L}}
$$

where, $\mathrm{IE}_{\mathrm{N}_{2} \mathrm{O}-\mathrm{ATD}}$ is $\mathrm{N}_{2} \mathrm{O}$ emissions from atmospheric deposition of $\mathrm{N}$ that volatilizes as $\mathrm{NO}_{\mathrm{X}}$ and $\mathrm{NH}_{3}, \mathrm{~kg} \mathrm{CO} \mathrm{CO}_{2}$-eq; $\mathrm{IE}_{\mathrm{N}_{2} \mathrm{O}-\mathrm{L}}$ is $\mathrm{N}_{2} \mathrm{O}$ emissions from $\mathrm{N}$ leaching and runoff, $\mathrm{kg} \mathrm{CO}_{2}$-eq.

$\mathrm{N}_{2} \mathrm{O}$ emissions from atmospheric deposition of $\mathrm{N}$ that volatilizes as $\mathrm{NO}_{\mathrm{X}}$ and $\mathrm{NH}_{3}$ are calculated by Equation (9).

$$
\mathrm{IE}_{\mathrm{N}_{2} \mathrm{O}-\mathrm{ATD}}=\mathrm{Frac}_{\mathrm{ATD}} \times\left(F_{\mathrm{SN}}+F_{\mathrm{ON}}\right) \times \mathrm{EF}_{13} \times 44 / 28 \times 265
$$

where, Frac $_{\mathrm{ATD}}$ is a fraction of chemical fertilizer and organic fertilizer that volatilizes as $\mathrm{NO}_{\mathrm{X}}$ and $\mathrm{NH}_{3}, 11.2 \%{ }^{[45]} ; \mathrm{EF}_{13}$ is the emission factor for atmosphere deposition of $\mathrm{N}$ on soils, $0.01 \mathrm{~kg} \mathrm{~N} / \mathrm{kg}^{[5]}$.

$\mathrm{N}_{2} \mathrm{O}$ emissions from $\mathrm{N}$ leaching and runoff are calculated by Equation (10).

$$
\mathrm{IE}_{\mathrm{N}_{2} \mathrm{O}-\mathrm{L}}=\left(F_{\mathrm{SN}}+F_{\mathrm{ON}}+F_{\mathrm{CR}}\right) \times \mathrm{Frac}_{\text {leach }} \times \mathrm{EF}_{14} \times 44 / 28 \times 265
$$

where, Frac $_{\text {leach }}$ is a fraction of $\mathrm{N}$ leaching and runoff, $12.6 \%{ }^{[45]}$; $\mathrm{EF}_{14}$ is emission factor for $\mathrm{N}$ leaching and runoff, $0.0075 \mathrm{~kg} \mathrm{~N} / \mathrm{kg}^{[5]}$.

3) $\mathrm{CH}_{4}$ emissions from rice cultivation

$\mathrm{CH}_{4}$ emissions from rice cultivation are calculated by Equation (11).

$$
\mathrm{CE}_{\text {paddy-CH}}=A_{\text {paddy }} \times \mathrm{EF}_{15} \times 28
$$

where, $A_{\text {paddy }}$ is planting area of rice, $\mathrm{hm}^{2} ; \mathrm{EF}_{15}$ is emission factor for rice cultivation, $168 \mathrm{~kg} \mathrm{CH}_{4} / \mathrm{hm}^{2[49]} ; 28$ is $\mathrm{CH}_{4} 100$-year Global Warming Potential from the Fifth Assessment Report of IPCC.

4) Straw burning emissions

Carbon emissions from straw burning are calculated by Equation (12).

$$
\mathrm{CE}_{\text {straw-burning }}=\mathrm{CE}_{\text {straw-burning-CO }}+\mathrm{CE}_{\text {straw-burning- } \mathrm{CH}_{4}}
$$

where, $\mathrm{CE}_{\text {straw-burning- } \mathrm{CO}_{2}}$ is carbon emissions from $\mathrm{CO}_{2}$ released by straw burning, $\mathrm{kg} \mathrm{CO}_{2}$-eq; $\mathrm{CE}_{\text {straw-burning-CH}}$ is carbon emissions from $\mathrm{CH}_{4}$ released by straw burning, $\mathrm{kg} \mathrm{CO}_{2}$-eq.

Carbon emissions from $\mathrm{CO}_{2}$ released by straw burning are calculated by Equation (13).

$$
\mathrm{CE}_{\text {straw-burning-CO }}=\sum_{i=1}^{n}\left(Y_{\mathrm{g}, j} \times \mathrm{R}_{\mathrm{S} / \mathrm{G}, j}\right) \times S_{\mathrm{B}} \times \mathrm{EF}_{16}
$$

where, $S_{\mathrm{B}}$ is straw burning rate, \%. According to official survey data by HLRA, the ratio of straw burning was $40 \%$ from 1999 to 2008, and it was $28 \%$ from 2009 to $2017 . \mathrm{EF}_{16}$ is the emission factor for $\mathrm{CO}_{2}$ released by straw burning, $1.3904 \mathrm{~kg} \mathrm{CO}-\mathrm{eq} / \mathrm{kg}^{[50]}$.

Carbon emissions from $\mathrm{CH}_{4}$ released by straw burning are 
calculated by Equation (14).

$$
\mathrm{CE}_{\text {straw-burning-CH }}=\sum_{i=1}^{n}\left(Y_{\mathrm{g}, j} \times \mathrm{R}_{\mathrm{S} / \mathrm{G}, j}\right) \times S_{\mathrm{B}} \times \mathrm{EF}_{17} \times 28
$$

where, $\mathrm{EF}_{17}$ is the emission factor for $\mathrm{CH}_{4}$ released by straw burning, $0.00219 \mathrm{~kg} \mathrm{CH}_{4} / \mathrm{kg}^{[50]}$.

2.3.3 Accounting method for carbon uptake

Carbon uptake is calculated by Equation (15).

$$
\mathrm{CS}=\left[\sum_{i=1}^{n}\left(Y_{\mathrm{g}, j} \times \mathrm{R}_{\mathrm{S} / \mathrm{G}, j} \times \mathrm{R}_{\mathrm{CSS}, j}\right)+\sum_{i=1}^{n}\left(Y_{\mathrm{g}, j} \times \mathrm{R}_{\mathrm{CSG}, j}\right)\right] \times 44 / 12
$$

where, CS is the carbon uptake of crop $j, \mathrm{~kg} \mathrm{CO}_{2}$-eq; $\mathrm{R}_{\mathrm{CSS}, j}$ is the straw carbon uptake rate of crop $j$; $\mathrm{R}_{\mathrm{CSG}, j}$ is the grain carbon uptake rate of crop $j$; $\mathrm{R}_{\mathrm{CSS}, j}$ and $\mathrm{R}_{\mathrm{CSG}, j}$ are shown in Table 2; 44/12 is the conversion coefficient between $\mathrm{C}$ and $\mathrm{CO}_{2}$.

Table 2 Carbon uptake rate for agriculture production system in HLRA

\begin{tabular}{ccc||ccc}
\hline Crop & $\mathrm{R}_{\mathrm{CSG}, j}$ & $\mathrm{R}_{\mathrm{CSS}, j}$ & Crop & $\mathrm{R}_{\mathrm{CSG}, j}$ & $\mathrm{R}_{\mathrm{CSS}, j}$ \\
\hline Rice & $0.44^{[51]}$ & $0.40^{[52]}$ & Potato & $0.36^{[42]}$ & $0.45^{[43]}$ \\
Wheat & $0.40^{[53]}$ & $0.42^{[54]}$ & Rapeseed & $0.45^{[43]}$ & $0.44^{[55]}$ \\
Maize & $0.44^{[56]}$ & $0.41^{[56]}$ & Other oil crop & $0.45^{[43]}$ & $0.44^{[55]}$ \\
Sorghum & $0.40^{*}$ & $0.42^{*}$ & Flax & $0.45^{[43]}$ & $0.45^{[43]}$ \\
Millet & $0.40^{*}$ & $0.42^{*}$ & Sugar beet & $0.41^{[43]}$ & $0.45^{[43]}$ \\
Barley & $0.40^{*}$ & $0.42^{*}$ & Tobacco & $0.45^{[43]}$ & $0.45^{[43]}$ \\
Other cereal & $0.40^{*}$ & $0.42^{*}$ & Vegetable & $0.44^{[43,57]}$ & $0.45^{[43]}$ \\
Soybean & $0.49^{[56]}$ & $0.44^{[56]}$ & Melon & $0.41^{[43,58]}$ & $0.45^{[43]}$ \\
Other beans & $0.49^{* *}$ & $0.44^{* *}$ & & & \\
\hline \multicolumn{7}{l}{ Notes: Data with superscripts “*” is replaced by wheat's data. } & Data with \\
superscripts "**” is replaced by soybean data.
\end{tabular}

\subsubsection{Evaluation indicators for carbon footprint}

In order to analyze carbon emissions and benefits, the four evaluation indicators are selected in this study as follows.

1) Carbon emissions per unit of area reflect the carbon emission level per area of the crop production system, which is calculated by Equation (16).

$$
\mathrm{CE}_{A}=\mathrm{CE} / A
$$

where, $\mathrm{CE}_{A}$ is carbon emissions per unit of area, $\mathrm{kg} \mathrm{CO}_{2}$-eq $/ \mathrm{hm} ; A$ is the total crop planting area, $\mathrm{hm}^{2}$.

2) Carbon emissions per unit of gross production value are carbon productive forces, which are calculated by Equation (17).

$$
\mathrm{CE}_{V}=\mathrm{CE} / V
$$

where, $\mathrm{CE}_{V}$ is carbon emissions per unit of gross production value, $10^{-4} \mathrm{~kg} \mathrm{CO}_{2}$-eq/RMB; $V$ is the gross production value of the crop production system, $10000 \mathrm{RMB}$.

3) Net carbon sequestrations per unit of area reflect the net carbon sequestration level per area of the crop production system, which is calculated by Equations (18)-(19).

$$
\begin{aligned}
& \mathrm{NCS}=\mathrm{CS}-\mathrm{CE} \\
& \mathrm{NCS}_{\mathrm{A}}=\mathrm{NCS} / A
\end{aligned}
$$

where, $\mathrm{NCS}_{A}$ is net carbon sequestrations per unit of area, $\mathrm{kg} \mathrm{CO}-\mathrm{eq} / \mathrm{hm}^{2}$.

2.3.5 Accounting method for planting structure simulating optimization

As a major carbon emission source, agriculture is the socioeconomic development foundation. Taking into consideration agriculture's sustainable development, it is imperative to mitigate the total amount of carbon emissions in agriculture. During crop production, cleaner technologies, which improve agricultural productivity and the efficiency of agricultural machinery operations ${ }^{[59]}$, can achieve the goals of GHG emissions reduction. At the same time, previous researches ${ }^{[30,60]}$ pointed out that adjustment of crop planting structure is also an effective way to reduce GHG emissions. So this study attempts to use this idea in HLRA. As the staple crops in HLRA, rice, soybean and maize are chosen as the research objects. This study conducted a multi-objective optimization model based on the adjustment of three staple crop planting structures, in which maximizing farmers' income is set as the objective function. Besides, reducing the carbon emissions per unit of gross production value could be a way to alleviate the contradiction between agricultural economic development and GHG emissions reduction. So the carbon emissions per unit of gross production value are taken as a constraint. The model is as follows:

1) Objective function

In order to protect farmers' interests, the maximization of farmers' incomes is the objective function in this study, which is expressed as Equation (20).

$$
\operatorname{Max} f=\sum_{i=1}^{3}\left(p_{i} \times y_{i}-c_{i}+b_{i}\right) \times s_{i}
$$

where, $p_{i}$ is the sale price of crop $i$, data from China Rural Statistical Yearbook 2018, rice is $2758 \mathrm{RMB} / \mathrm{t}$, soybean is $3766 \mathrm{RMB} / \mathrm{t}$ and maize is $1644 \mathrm{RMB} / \mathrm{t}$; $y_{i}$ is yield of crop $i$, rice is $8.97 \mathrm{t} / \mathrm{hm}^{2}$, soybean is $2.47 \mathrm{t} / \mathrm{hm}^{2}$ and maize is $9.20 \mathrm{t} / \mathrm{hm}^{2} ; c_{i}$ is production cost of crop $i$, data obtained by field investigation, rice is $14315.27 \mathrm{RMB} / \mathrm{hm}^{2}$, soybean is $8603.36 \mathrm{RMB} / \mathrm{hm}^{2}$ and maize is $11199.75 \mathrm{RMB} / \mathrm{hm}^{2} ; b_{i}$ is the subsidy for crop $i, \mathrm{RMB} / \mathrm{hm}^{2}$. The subsidies of three staple crops are composed of farmland protection subsidies and producer subsidies. The cereal crop farmland protection subsidy was $1075.5 \mathrm{RMB} / \mathrm{hm}^{2}$. And the producer subsidy of soybean is $3677.4 \mathrm{RMB} / \mathrm{hm}^{2}$ and maize is $3077.4 \mathrm{RMB} / \mathrm{hm}^{2} . \quad s_{i}$ is simulated planting area of crop $i, \mathrm{hm}^{2} ; i=1$, 2,3 , where 1 represents rice, 2 represents soybean and 3 represents maize.

2) Constraint for three staple cereal crop planting area

According to statistics, the planting area of three staple cereal crops in HLRA was 2.742-2.780 million $\mathrm{hm}^{2}$ from 2014 to 2017, which fluctuated slightly from year to year. Therefore, the variation range of three staple cereal crop planting areas in HLRA is taken as a constraint, which is expressed as Equation (21).

$$
s_{1}+s_{2}+s_{3} \leq 2779705
$$

3) Constraint for carbon emissions per unit of gross production value

The adjusted carbon emissions per unit of gross production value of three staple cereal crops in HLRA are not greater than that in 2017. And this study conducted a simulation analysis of the impact on the planting structure of three staple cereal crops if carbon emissions per unit of gross production value declined by a certain proportion, which is expressed as Equation (22).

$$
\frac{\sum_{i=1}^{3} c p_{i} \times s_{i}}{\sum_{i=1}^{3} p_{i} \times y_{i} \times s_{i}} \leq c e v \times(1-\alpha)
$$

where, $c p_{i}$ is carbon emissions per area of crop $i, \mathrm{~kg} / \mathrm{hm}^{2}$. According to the carbon emission calculation method and field investigation of three staple crops production process, the carbon emissions per unit area of rice is $7999.40 \mathrm{~kg} / \mathrm{hm}^{2}$, soybean is $2385.98 \mathrm{~kg} / \mathrm{hm}^{2}$ and maize is $2866.39 \mathrm{~kg} / \mathrm{hm}^{2}$; cev is carbon emissions per unit of gross production value of three staple crops in $2017,0.2999 \mathrm{~kg} / \mathrm{RMB}$, which is calculated based on the statistic of planting area in 2017; $\alpha$ is the simulating decline proportion of carbon emissions per unit of gross production value, $\%$. 
4) Constraint for soybean yield

As the major soybean importer, the expansion of the domestic soybean planting area would be conducive to meeting market demand in China. Therefore, this study conducted a simulation analysis of the impact on the three staple cereal crop planting structures if the total soybean production increases by a certain proportion, which is expressed as Equation (23).

$$
s_{2} \times y_{2} \geq Y_{2} \times(1+\beta)
$$

where, $\beta$ is the growth ratio of simulated soybean production, $\% ; Y_{2}$ is the total soybean production in 2017, $2118782 \mathrm{t}$.

In this study, two scenarios were simulated, both with the same objective function of maximizing farmers' incomes. In the first scenario, the constraint $\beta$ was set to 0 for the total soybean production growth, and the change in the planting area of the three crops was simulated when $\alpha$ varied from 0 to $5 \%$, which indicated the decrease rate in carbon emissions per unit of gross production value. In the second scenario, $\alpha$ was set to $2 \%$, and the change in the planting area of the three crops was simulated when $\beta$ varied from 0 to $50 \%$.

\section{Results and discussion}

\subsection{Analysis of carbon emissions of crops production}

Figure 2 indicated the annual carbon emissions of the crops production system in HLRA between 2000 and 2017. In general, the carbon emissions tended to be stable from 2000 to 2003. But the carbon emissions increased rapidly from 2003 to 2013, with an average annual growth rate of $8.86 \%$, reaching a maximum value of 30.1 billion $\mathrm{kg}$ in 2013. After that, carbon emissions decreased with an average annual decline rate of $2.14 \%$. In 2017, the total carbon emissions in HLRA were $2.84 \times 10^{10} \mathrm{~kg}$. Besides, carbon emissions were composed of four major parts: agricultural inputs, $\mathrm{N}_{2} \mathrm{O}$ emissions from managed soils, $\mathrm{CH}_{4}$ emissions from rice cultivation and straw burning emissions. And the four parts accounted for $23.81 \%, 8.91 \%, 23.91 \%$, and $43.36 \%$, respectively, which were stable during these years.

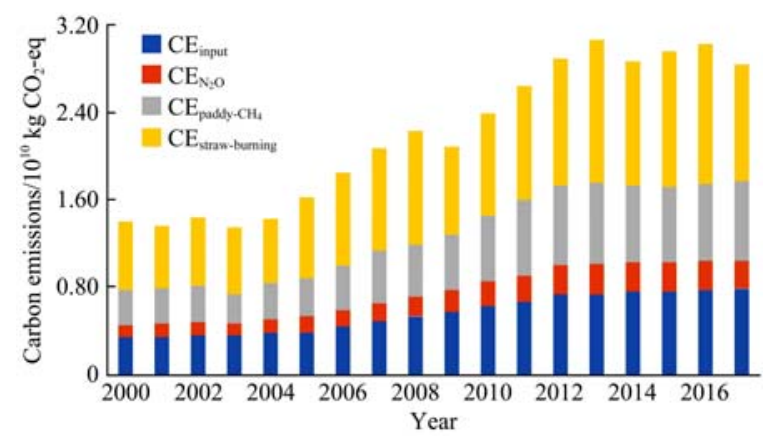

Figure 2 Carbon emissions of crop production system

The annual carbon emissions of agricultural inputs were presented in Figure 3. The carbon emissions of agricultural inputs tended to be stable from 2000 to 2003. But the carbon emissions of agricultural inputs increased rapidly from 2003 to 2012, with an average annual growth rate of $8.87 \%$, reaching a maximum value of 6.91 billion $\mathrm{kg}$ in 2012. After that, the carbon emissions of agricultural inputs inclined to be stable. Moreover, the carbon emissions of nitrogen fertilizer, agricultural machinery, diesel and electricity accounted for more than $74.04 \%$ of the total, which was the main component. Carbon emissions of agricultural machinery exceeded nitrogen fertilizer for the first time in 2015, which accounted for the largest part of agricultural inputs and was about a quarter of the total.

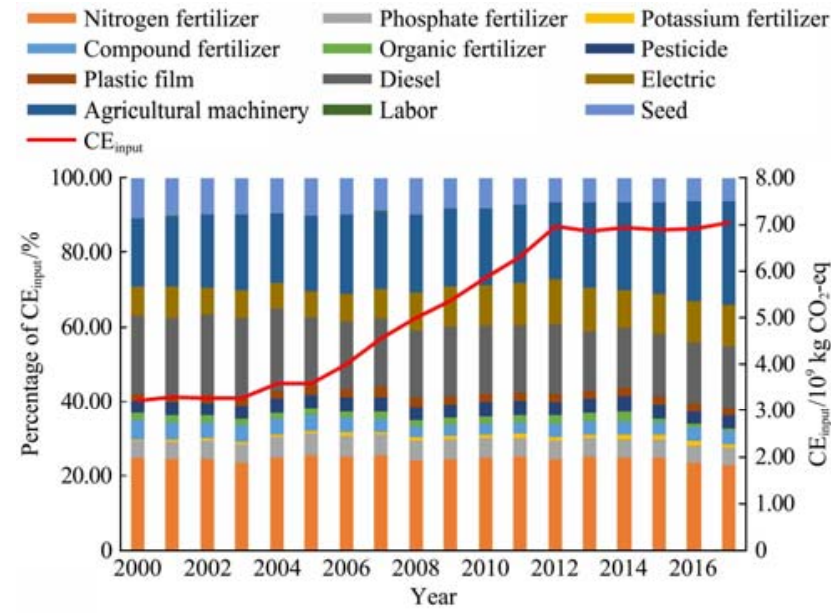

Figure 3 Carbon emissions of agricultural inputs $\left(\mathrm{CE}_{\text {input }}\right)$ and their proportion

The annual $\mathrm{N}_{2} \mathrm{O}$ emissions from managed soils were shown in Figure 4. The $\mathrm{N}_{2} \mathrm{O}$ emissions from managed soils tended to be stable from 2000 to 2003. But $\mathrm{N}_{2} \mathrm{O}$ emissions from managed soils increased rapidly from 2003 to 2013, with an average annual growth rate of $9.17 \%$, reaching a maximum value of 2.78 billion $\mathrm{kg}$ in 2013. Then, carbon emissions decreased from 2013 to 2017. Moreover, the direct $\mathrm{N}_{2} \mathrm{O}$ emissions from managed soils played an important role, and the $\mathrm{N}$ input from fertilizer and crop straw returning were the main sources.

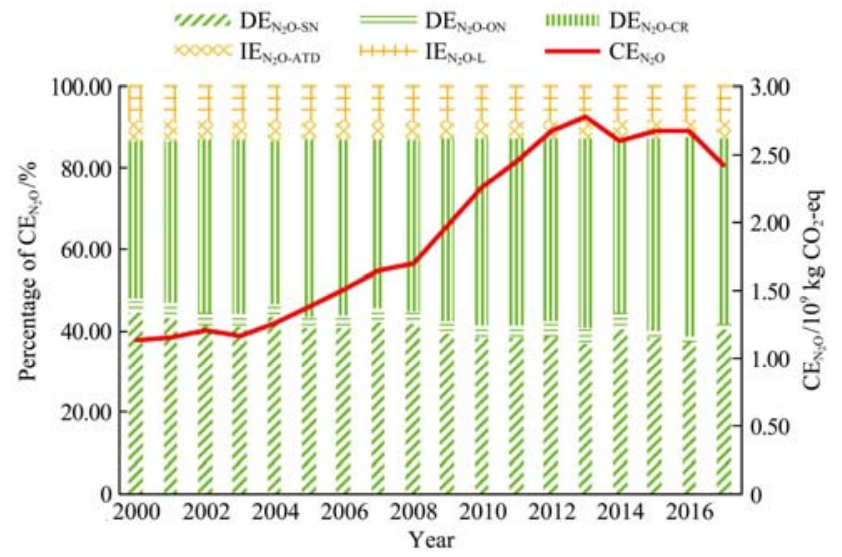

Figure 4 Carbon emissions of $\mathrm{N}_{2} \mathrm{O}$ emissions from managed soils $\left(\mathrm{CE}_{\mathrm{N}_{2} \mathrm{O}}\right)$ and its proportion

$\mathrm{CH}_{4}$ emissions from rice cultivation increased rapidly, due to the increase of the rice planting area in HLRA. Compared with 0.677 million $\mathrm{hm}^{2}$ in 2000, the rice planting area was 1.555 million $\mathrm{hm}^{2}$ in 2017 and accounted for $54.36 \%$ of the total planting area in HLRA. Furthermore, the straw burning emissions increased initially with the increase in the crops planting area. Owing to the ratio of straw burning changed from $40 \%$ in 2008 to $28 \%$ in 2009 , the straw burning emissions declined in 2009 compared to it in 2008 .

\subsection{Analysis of carbon uptake of crops production}

Figure 5 demonstrated the annual carbon uptake of the crops production system in HLRA from 2000 to 2017. In general, carbon uptake tended to be stable from 2000 to 2003 . But the carbon uptake increased rapidly from 2003 to 2012, with an average annual growth rate of $12.92 \%$, reaching a maximum value of 90.3 billion $\mathrm{kg}$ in 2012. After that, carbon emissions decreased with an average annual decline rate of $3.27 \%$. In 2017, the total carbon uptake in HLRA was $7.49 \times 10^{10} \mathrm{~kg}$. Besides, the carbon uptake was composed of grain carbon uptake and straw carbon 
uptake, which accounted for $47.65 \%$ and $52.35 \%$ respectively over the years.

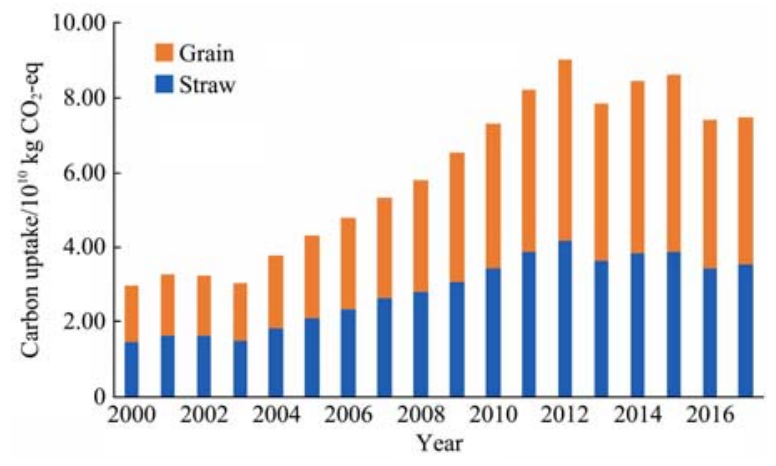

Figure 5 Carbon uptake of crop production system

The annual grain carbon uptake was presented in Figure 6. The grain carbon uptake tended to be stable from 2000 to 2003 . But grain carbon uptake increased rapidly between 2003 and 2012, with an average annual growth rate of $12.28 \%$, reaching a maximum value of 41.9 billion $\mathrm{kg}$ in 2012. After that, grain carbon uptake declined with an average annual decline rate of $3.10 \%$. Moreover, the carbon uptake of rice, maize and soybean accounted for $54.47 \%, 21.29 \%$ and $10.68 \%$ of grain carbon uptake, which were the main components. And maize surpassed soybeans in 2005 and became the second-largest crop in carbon uptake. However, the carbon uptake of maize decreased significantly since 2015 , with an annual average decline rate of $28.02 \%$, while soybean carbon uptake increased significantly, with an average annual growth rate of $128.43 \%$.

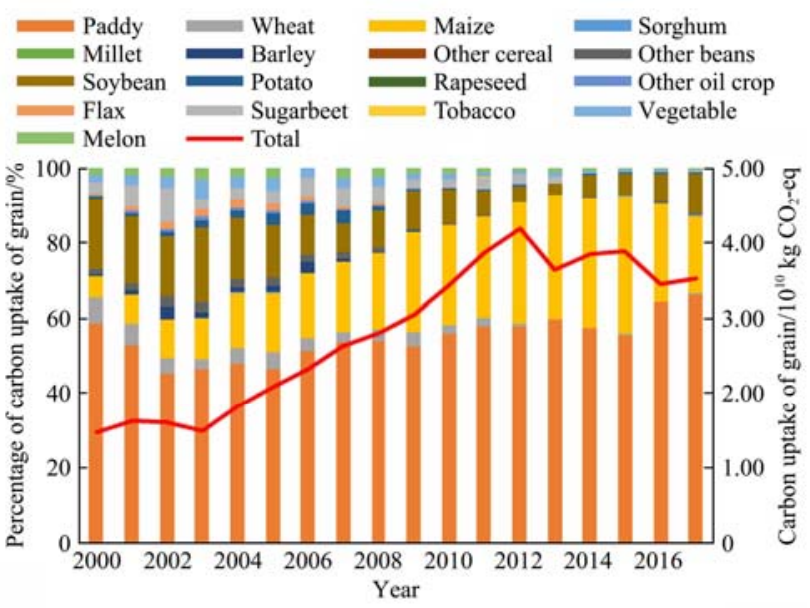

Figure 6 Carbon uptake of grains and its proportion

The annual straw carbon uptake was demonstrated in Figure 7. The straw carbon uptake tended to be stable from 2000 to 2003 . But straw carbon uptake increased rapidly between 2003 and 2012, with an average annual growth rate of $13.35 \%$, reaching a maximum value of 48.4 billion $\mathrm{kg}$ in 2012. After that, straw carbon uptake decreased with an average annual decline rate of $3.40 \%$. Moreover, the carbon uptake of rice straw, maize stalk and soybean straw accounted for about $43.81 \%, 32.94 \%$ and $15.31 \%$ of straw carbon uptake respectively, which were the main components. Besides, maize stalks exceeded rice straw and became the largest crop of carbon uptake in 2012, but it declined significantly since 2015 .

\subsection{Evaluation results of carbon footprint}

\subsubsection{Carbon emissions per unit of area}

Figure 8 indicated the annual carbon emissions per unit of area of the crop production system in HLRA between 2000 and 2017.
The carbon emissions per unit of area tended to be stable from 2000 to 2004. But the carbon emissions per unit of area increased rapidly between 2004 and 2013, with an average annual growth rate of $5.38 \%$, reaching a maximum value of $10600 \mathrm{~kg} / \mathrm{hm}^{2}$ in 2013. After that, the carbon emissions per unit of area decreased with an average annual decline rate of $2.32 \%$.

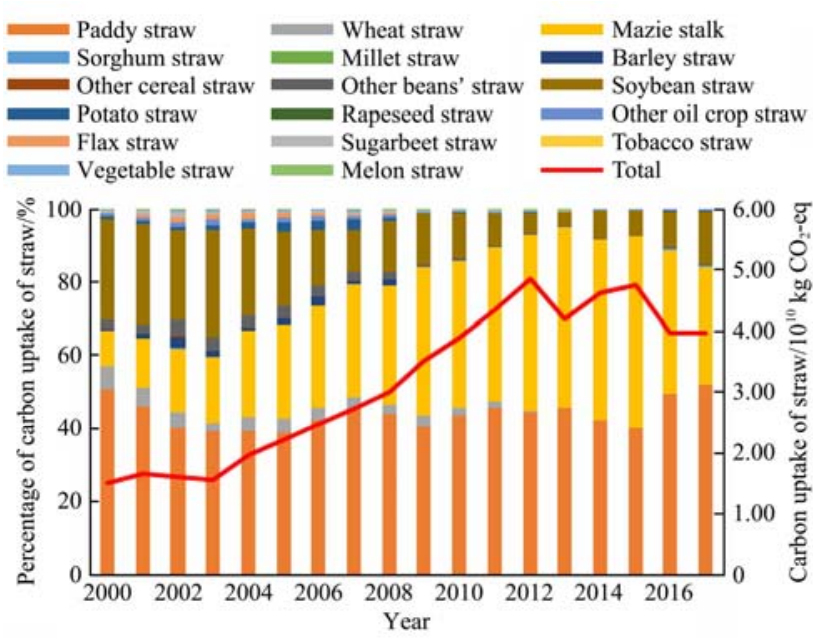

Figure 7 Carbon uptake of straws and its proportion

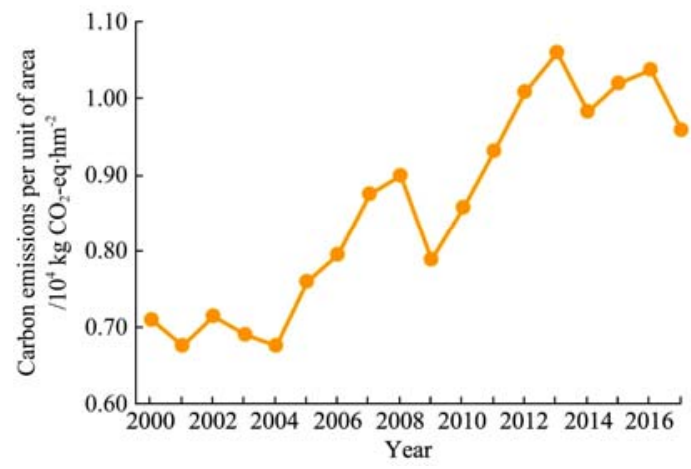

Figure 8 Carbon emissions per unit of area

\subsubsection{Carbon emissions per unit of gross production value}

Figure 9 showed the annual carbon emissions per unit of gross production value of the crops production system in HLRA between 2000 and 2017. The carbon emissions per unit of gross production value fluctuated greatly from 2000 to 2002 . It reached the highest value of $11500 \mathrm{~kg} / 10^{4} \mathrm{RMB}$ in 2002 . After that, the carbon emissions per unit of gross production value declined with an average annual decline rate of $7.13 \%$.

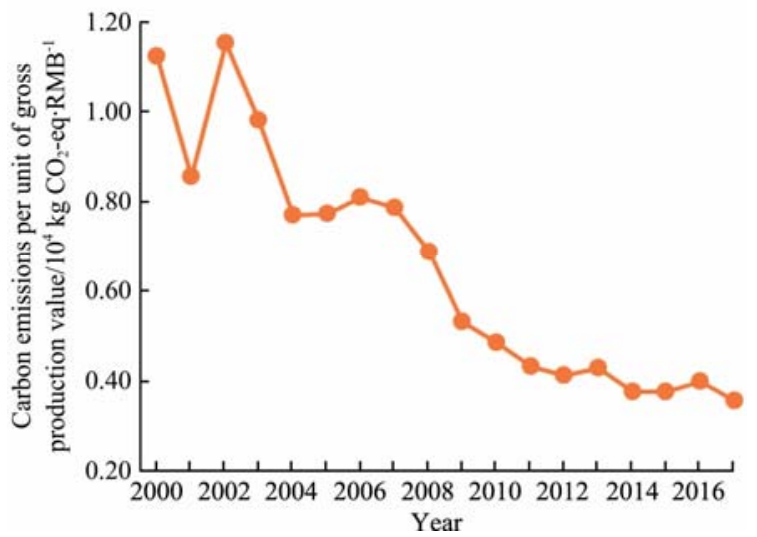

Figure 9 Carbon emissions per unit of gross production value

3.3.3 Net carbon sequestrations per unit of area

Figure 10 demonstrated the annual net carbon sequestrations per unit of area of the crops production system in HLRA between 
2000 and 2017, in which carbon sequestrations were more than the carbon emissions. The net carbon sequestrations per unit of area increased from 2000 to 2012, with an average annual growth rate of $8.85 \%$, reaching a maximum value of $21800 \mathrm{~kg} / \mathrm{hm}^{2}$ in 2012 . After that, the net carbon sequestrations per area declined with an average annual decline rate of $4.04 \%$.

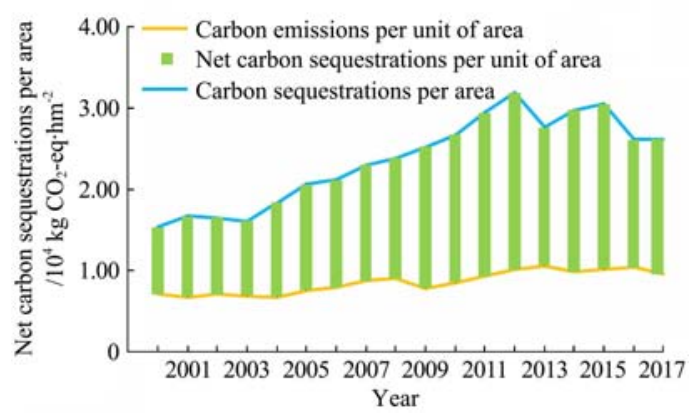

Figure 10 Net carbon sequestrations per unit of area

According to these results, the carbon sequestrations of crop production system were greater than the carbon emissions, which showed carbon sequestration benefits. Moreover, carbon emissions per unit of area and the carbon emissions per unit of gross production value declined in recent years. And net carbon sequestrations per unit of area increased. It indicated that crop production in HLRA not only developed rapidly but also improved economic, environmental benefits.

\subsection{Simulating optimization result of planting structure}

3.4.1 Simulation analysis of carbon emissions per unit of gross production value

Figure 11 indicates that with the decrease of carbon emission per unit of gross production value, the planting area of rice decreased, the planting area of maize increased, the planting area of soybean remained the same, and farmers' incomes decreased. While the carbon emission per unit of gross production value decreased by $5 \%$, the planting area of rice, soybean, and maize were $1.236 \times 10^{6} \mathrm{hm}^{2}, \quad 0.774 \times 10^{6} \mathrm{hm}^{2}$ and $0.769 \times 10^{6} \mathrm{hm}^{2}$, respectively. Compared with the planting area before, the planting area of rice decreased by $20.7 \%$ and the planting area of maize increased by $72.1 \%$, mainly because the carbon emissions per unit of gross production value of rice $(0.3232 \mathrm{~kg} / \mathrm{RMB})>$ soybean $(0.3085 \mathrm{~kg} / \mathrm{RMB})>$ maize $(0.1577 \mathrm{~kg} / \mathrm{RMB})$. Under the constraint that the carbon emission per unit of gross production decreased, the planting area of crops with low carbon emission per unit of gross production value should increase, which led to the results that the planting area of maize increased and the planting area of rice decreased. However, farmers' incomes decreased, mainly since the economic return per unit of gross production value of rice was higher than maize. This simulation indicated that if carbon emission per unit of production value of the planting production system was reduced, the planting area of rice would reduce, and at the same time, farmers' incomes declined.

\subsubsection{Simulation analysis of total soybean yield}

Figure 12 shows that with the growth of total soybean production, the planting area of soybeans increased rapidly, while the planting area of rice and maize decreased simultaneously. While the total soybean production increased by $50 \%$, the planting area of soybean increased by $3.8 \times 10^{6} \mathrm{hm}^{2}$. Due to the total planting area remaining the same, the planting area of rice decreased by $2.0 \times 10^{6} \mathrm{hm}^{2}$, and the planting area of maize decreased by $1.8 \times 10^{6} \mathrm{hm}^{2}$. The reason why the reducing area of maize and rice were similar was that the economic return per unit area of rice was higher and the carbon emission per area of maize was lower. As the total soybean production increased, farmers' incomes gradually decreased, mainly because the economic return per unit area of soybean was lower than rice or maize. It suggested that if soybean production was increased in HLRA, the planting area of rice and maize would be reduced and the problem of farmers' incomes decreasing occurred.

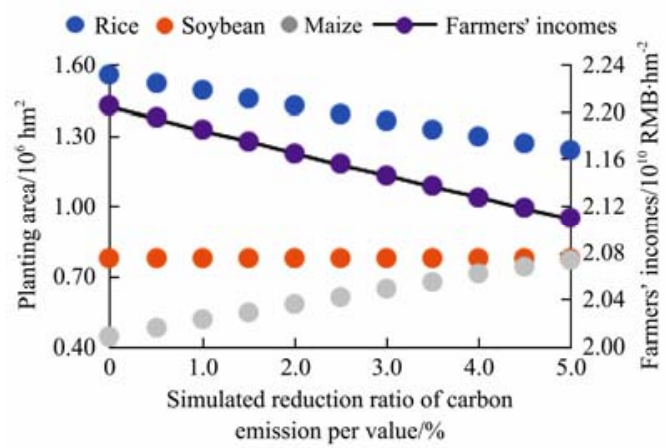

Figure 11 Trends of planting area of three major grain crops accompanied by the decrease of carbon emissions per unit of gross production value

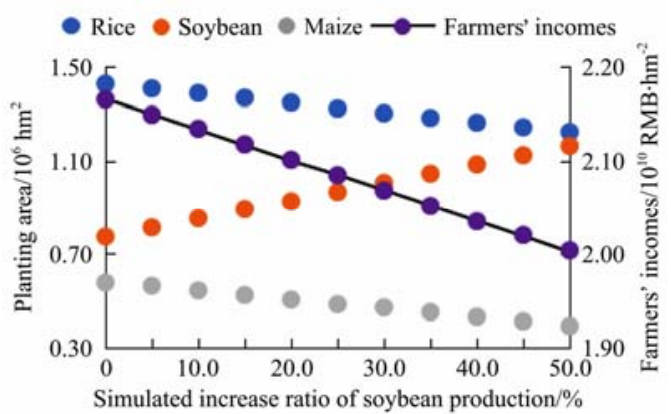

Figure 12 Trends of planting area of three major grain crops accompanied by the increase of total soybean production

\section{Discussion}

The carbon emissions of the planting production system in HLRA were analyzed, including carbon emissions from agricultural inputs, $\mathrm{N}_{2} \mathrm{O}$ emissions from managed soils, $\mathrm{CH}_{4}$ emissions from rice cultivation, and straw burning emissions.

First, straw burning emissions accounted for an average of $43.36 \%$ over the years, which were the largest sources of carbon emissions from the planting production system in HLRA (Figure 2). Crop straws were supposed to fix carbon (Figure 5), but their large straw burning significantly increased carbon emissions and polluted the atmosphere. Assuming straw burning was converted to comprehensive utilization in 2017 , disregarding the economic benefits, for the time being, $39.03 \%$ dropped in the simulated carbon emissions per unit area and $22.59 \%$ dropped in net carbon uptake per unit area. So, it was urgent to achieve crop straw comprehensive utilization and reduce straw burning, which was conducive to agriculture low-carbonization development ${ }^{[61]}$. Through interviews with farmers, they also wanted to utilize crop straws in multiple ways. But the bottleneck was the straw collection, storage and transportation. During the crop harvest period in autumn, such as the lack of agricultural machinery operation time, the lack of straw balers and the production cost increases, the straws were little bundled and left the field quickly. Therefore, it was suggested that the local governments should encourage research institutes and farms to work together to optimize more appropriate technology or farm equipment for crop 
straw harvesting, storage and transportation, to realize the purpose of low cost.

Secondly, $\mathrm{CH}_{4}$ emissions from rice cultivation were the second-largest source of carbon emissions in HLRA, accounting for an average of $23.91 \%$ over the years (Figure 2). This was mainly due to the anaerobic environment formed by flooding, which could be reduced by improved irrigations. Recent studies had shown that improved irrigations such as controlled irrigation $^{[62,63]}$, leaf-age mode irrigation ${ }^{[63]}$, and alternate wet and dry irrigation ${ }^{[64,65]}$ could significantly reduce carbon emissions from rice. Through field surveys, conventional irrigation and controlled irrigation were the main rice irrigation modes in HLRA $^{[66]}$. And the current purpose of improving irrigation was to save water and increase yields. However, in the need of promoting green agriculture, the ways to achieve low carbon emissions in rice cultivation need to be considered in the future. Therefore, it was recommended that the issue of carbon emissions should be considered at the same time when promoting irrigation technology in HLRA.

Furthermore, the average percentage of carbon emissions from agricultural inputs reached $23.81 \%$ over the years, which was slightly smaller than the $\mathrm{CH}_{4}$ emissions from rice cultivation. It was mainly composed of carbon emissions from nitrogen fertilizers, agricultural machinery, diesel, and electricity. Carbon emissions from nitrogen fertilizers accounted for the highest percentage, reaching $24.19 \%$ on average (Figure 2). It was the application of nitrogen fertilizers that guaranteed food security in the agricultural production process. Through previous researches, it was found that soil nitrogen in farmland soils in HLRA was in a balanced state, with nutrient utilization efficiency of $51.03 \%{ }^{[67]}$. Compared with developed countries such as the United States ${ }^{[68]}$, there was still plenty of room for improvement. Therefore, nutrient management techniques could be adopted, such as side-deep fertilization ${ }^{[69]}$, to improve nutrient utilization efficiency and moderately reduce nitrogen fertilizer application, and then cut down carbon emissions from nitrogen fertilizers and $\mathrm{N}_{2} \mathrm{O}$ emissions from managed soils.

In the simulation and optimization of cropping structure, the simulation analysis of two scenarios was carried out in the planting production system. In the scenario of decreasing carbon emission per unit of gross production value, since the carbon emission per unit of gross production value of maize was almost half of rice, the optimization results showed that the planting area of rice reduced and the planting area of maize increased, and the problem of farmers' incomes declining was brought about. Enriching farmers' income had always been a priority work of the Chinese government. Therefore, in the future, if the cropping structure in HLRA was adjusted according to carbon emissions, some methods were needed considering such as increasing farmers' production subsidies to solve the problem of farmers' incomes declining. Besides, new rice varieties were also beneficial to carbon emission reduction $^{[70]}$.

In the scenario of increasing the total soybean production, it was found that the planting area of soybean grew, while the planting area of rice and maize declined rapidly. The underlying reason was the low soybean yield of $2467.5 \mathrm{~kg} / \mathrm{hm}^{2}$. Compared to the soybean yield of $2748.8 \mathrm{~kg} / \mathrm{hm}^{2}$ in Brazil, there was a large gap. In that case, the low soybean yield required more land to plant soybean. Therefore, further exploration of soybean yield potential was needed, from various aspects such as soybean variety selection and breeding ${ }^{[71]}$, agronomic practices ${ }^{[72]}$ and mechanized production to improve soybean yields and enhance soybean market supply in the future.

\section{Conclusions}

This study evaluated and analyzed the carbon footprint of the planting production system in HLRA from 2000 to 2017, of which the total carbon emissions and carbon uptake showed a "stable-growth-decline" trend. In 2017, the total carbon emissions of HLRA were $2.84 \times 10^{10} \mathrm{~kg}$, and the total carbon uptake was $7.49 \times 10^{10} \mathrm{~kg}$. In terms of carbon emissions, the carbon emissions from agricultural inputs, $\mathrm{N}_{2} \mathrm{O}$ emissions from managed soils, $\mathrm{CH}_{4}$ emissions from rice cultivation and straw burning emissions accounted for $23.81 \%, 8.91 \%, 23.91 \%$ and $43.36 \%$ on average over the years respectively, and the proportions changed little. The straw burning emissions were the largest source of carbon emissions in HLRA. There were still technical difficulties in the low-cost straw leaving the field, but this category had the greatest potential for emission reduction. In terms of carbon uptake, seed carbon uptake and straw carbon uptake accounted for $47.65 \%$ and $52.35 \%$ of the total carbon uptake on average over the years, and the proportion changed little. On the whole, the carbon uptake was greater than the carbon emissions of the planting production system in HLRA. The carbon emissions per unit area and carbon emissions per unit of gross production value both showed a decreasing trend, which indicated that the rapid development had been accompanied by an increase in economic and environmental benefits, of the planting production system. To further reduce carbon emissions in HLRA, it was suggested that the local governments should increase the comprehensive utilization level of straw resources to reduce straw burning emissions. Further, something more could be done, such as promoting controlled irrigation to reduce $\mathrm{CH}_{4}$ emissions from rice cultivation; fertilization methods improvement and nitrogen fertilizer application reduction to low down carbon emissions from agricultural inputs and $\mathrm{N}_{2} \mathrm{O}$ emissions from managed soils.

By simulating and optimizing the cropping structure of the three major crops in HLRA, it was found that a decrease in carbon emissions from the planting production system might require a reduction in the planting area of rice and a moderate increase in the planting area of maize and soybeans, which led to a decrease in farmers' incomes. The low soybean yields required more land to plant soybean. Therefore, it was recommended that the local governments should deeply exploit the soybean yield potential from variety selection and breeding, techniques improvement, and compensate for the decline in farmers' incomes by increasing their production subsidies.

At this stage, only two aspects, farmers' incomes and carbon emissions, were considered in this paper to simulate and optimize the cropping structure of the planting production system. In future studies, if soil health or water consumption were included in the simulation and multi-objective optimization was carried out, it would be possible to provide more comprehensive suggestions for cropping structure optimization and agricultural green development in HLRA.

\section{Acknowledgements}

This research was supported by the National Key Research and Development Project, Ministry of Science and Technology (Grant No. 2016YFE0204600), and the Innovation Team Project of the Ministry of Education (Grant No. IRT_17R105). 


\section{[References]}

[1] IPCC. Global Warming of $1.5^{\circ} \mathrm{C} 2018$ Available: https://www.ipcc.ch/sr15/. Accessed on [2019-11-17].

[2] Allen M R, Frame D J, Huntingford C, Jones C D, Lowe J A, Meinshausen $\mathrm{M}$, et al. Warming caused by cumulative carbon emissions towards the trillionth tonne. Nature, 2009; 458(7242): 1163-1166.

[3] Meinshausen M, Meinshausen N, Hare W, Raper S C B, Frieler K, Knutti $\mathrm{R}$, et al. Greenhouse-gas emission targets for limiting global warming to 2 degrees C. Nature, 2009; 458(7242): 1158-1162.

[4] Thomas C D, Cameron A, Green R E, Bakkenes M, Beaumont L J, Collingham Y C, et al. Extinction risk from climate change. Nature, 2004; 427(6970): 145-148.

[5] IPCC. Climate Change 2014: Synthesis Report. Contribution of Working Groups I, II and III to the Fifth Assessment Report of the Intergovernmental Panel on Climate Change. Geneva, 2014; 151p.

[6] Smith P, Martino D, Cai ZC, Gwary D, Janzen H, Kumar P, et al. Greenhouse gas mitigation in agriculture. Philosophical Transactions of the Royal Society B-Biological Sciences, 2008; 363(1492): 789-813.

[7] West T O, Marland G. A synthesis of carbon sequestration, carbon emissions, and net carbon flux in agriculture: comparing tillage practices in the United States. Agriculture Ecosystems \& Environment, 2002; 91(1-3): 217-232.

[8] Cheng K, Pan G X, Smith P, Luo T, Li L Q, Zheng J W, et al. Carbon footprint of China's crop production-An estimation using agro-statistics data over 1993-2007. Agriculture Ecosystems \& Environment, 2011; 142(3-4): 231-237.

[9] Lin J Y, Hu Y C, Cui S H, Kang J F, Xu L L. Carbon footprints of food production in China (1979-2009). Journal of Cleaner Production, 2015; 90: 97-103.

[10] Yan Z G, Hou F J, Yan T H. Evaluation of greenhouse gas emissions from three contrasting integrated crop and livestock production systems during 1991-2016 in Gansu of China. Pakistan Journal of Agricultural Sciences, 2019; 56(2): 469-480.

[11] Franchetti M, Apul D. Carbon footprint analysis: concepts, methods, implementation, and case studies. Boca Raton: CRC Press, 2012; 270p.

[12] Hillier J, Hawes C, Squire G, Hilton A, Wale S, Smith P. The carbon footprints of food crop production. International Journal of Agricultural Sustainability, 2009; 7(2): 107-118.

[13] Zhang D, Shen J B, Zhang F S, Li Y E, Zhang W F. Carbon footprint of grain production in China. Scientific Reports, 2017; 7: 4126. doi: 10.1038/s41598-017-04182-x.

[14] Guenther J, Thevs N, Gusovius H J, Sigmund I, Brueckner T, Beckmann V, et al. Carbon and phosphorus footprint of the cotton production in Xinjiang, China, in comparison to an alternative fibre (Apocynum) from Central Asia. Journal of Cleaner Production, 2017; 148: 490-497.

[15] Linquist B A, Marcos M, Adviento-Borbe M A, Anders M, Harrell D, Linscombe $\mathrm{S}$, et al. Greenhouse gas emissions and management practices that affect emissions in US rice systems. Journal of Environmental Quality, 2018; 47(3): 395-409.

[16] Snyder C S, Bruulsema T W, Jensen T L, Fixen P E. Review of greenhouse gas emissions from crop production systems and fertilizer management effects. Agriculture Ecosystems \& Environment, 2009; 133(3-4): 247-266.

[17] He L Y, Zhang A F, Wang X D, Li J, Hussain Q. Effects of different tillage practices on the carbon footprint of wheat and maize production in the Loess Plateau of China. Journal of Cleaner Production, 2019; 234: 297-305.

[18] Lal B, Gautam P, Nayak A K, Panda B B, Bihari P, Tripathi R, et al. Energy and carbon budgeting of tillage for environmentally clean and resilient soil health of rice-maize cropping system. Journal of Cleaner Production, 2019; 226: 815-830.

[19] Jiang Z H, Zhong Y M, Yang J P, Wu Y X Y, Li H, Zheng L. Effect of nitrogen fertilizer rates on carbon footprint and ecosystem service of carbon sequestration in rice production. Science of the Total Environment, 2019; 670: 210-217.

[20] Liu Q, Liu B J, Ambus P, Zhang Y H, Hansen V, Lin Z B, et al. Carbon footprint of rice production under biochar amendment - a case study in a Chinese rice cropping system. Global Change Biology Bioenergy, 2016; 8(1): 148-159.

[21] Wang Z B, Chen J, Mao S C, Han Y C, Chen F, Zhang L F, et al. Comparison of greenhouse gas emissions of chemical fertilizer types in China's crop production. Journal of Cleaner Production, 2017; 141: $1267-1274$.
[22] Wang Z B, Wen X Y, Zhang H L, Lu X H, Chen F. Net energy yield and carbon footprint of summer corn under different $\mathrm{N}$ fertilizer rates in the North China Plain. Journal of Integrative Agriculture, 2015; 14(8): 1534-1541.

[23] Borsato E, Martello M, Marinello F, Bortolini L. Environmental and economic sustainability assessment for two different sprinkler and a drip irrigation systems: A case study on maize cropping. Agriculture-Basel, 2019; 9(9): 187 . doi: 10.3390/agriculture9090187.

[24] Zhang W S, He X M, Zhang Z D, Gong S, Zhang Q, Zhang W, et al Carbon footprint assessment for irrigated and rainfed maize (Zea mays L.) production on the Loess Plateau of China. Biosystems Engineering, 2018; 167: 75-86.

[25] Eranki P L, Devkota J, Landis A E. Carbon footprint of corn-soy-oats rotations in the US Midwest using data from real biological farm management practices. Journal of Cleaner Production, 2019; 210: 170-180.

[26] Singh R J, Meena R L, Sharma N K, Kumar S, Kumar K, Kumar D. Economics, energy, and environmental assessment of diversified crop rotations in sub-Himalayas of India. Environmental Monitoring and Assessment, 2016; 188: 79. doi: 10.1007/s10661-015-5085-2.

[27] Yang X L, Gao W S, Zhang M, Chen Y Q, Sui P. Reducing agricultural carbon footprint through diversified crop rotation systems in the North China Plain. Journal of Cleaner Production, 2014; 76: 131-139.

[28] Franzluebbers A J. Cattle grazing effects on the environment: Greenhouse gas emissions and carbon footprint. Management strategies for sustainable cattle production in southern pastures. Academic Press, 2020; pp.11-34. doi: 10.1016/B978-0-12-814474-9.00002-5.

[29] Li Z J, Sui P, Wang X L, Yang X L, Long P, Cui J X, et al. Comparison of net GHG emissions between separated system and crop-swine integrated system in the North China Plain. Journal of Cleaner Production, 2017; 149: 653-664.

[30] Wang X L, Chen Y, Chen X W, He R R, Guan Y S, Gu Y W, et al. Crop production pushes up greenhouse gases emissions in China: evidence from carbon footprint analysis based on national statistics data. Sustainability, 2019; 11(18): 1-18.

[31] Zhang W F, Dou Z X, He P, Ju X T, Powlson D, Chadwick D, et al. New technologies reduce greenhouse gas emissions from nitrogenous fertilizer in China. Proceedings of the National Academy of Sciences of the United States of America, 2013; 110(21): 8375-8380.

[32] Chen S, Lu F, Wang X K. Estimation of greenhouse gases emission factors for China's nitrogen, phosphate and potash fertilizers. Acta Ecologica Sinica, 2015; 35(19): 6371-6383.

[33] Liu Y, Cheng Z, Wang Y N, Li S B. Study on greenhouse gas emission of nitrogen based on life cycle assessment. Environment and Sustainable Development, 2015; 40(3): 66-68.

[34] Ji C L, Ding M, Wang B X, Wang C M, Zhao Y. Comparative evaluation of chemical and organic fertilizer on the base of life cycle analysis methods. Chinese Journal of Soil Science, 2012; 43(2): 412-417. (in Chinese)

[35] Li J Z. Technology evaluation for greenhouse gas mitigation in cropland ecosystem and case studies. PhD dissertation. Chinese Academy of Agricultural Sciences Dissertation, 2012; 88p. (in Chinese)

[36] Zhang G, Lu F, Huang Z G, Chen S, Wang X K. Estimations of application dosage and greenhouse gas emission of chemical pesticides in staple crops in China. Chinese Journal of Applied Ecology, 2016; 27(9): 2875-2883. (in Chinese)

[37] Huang $\mathrm{Z} \mathrm{H}$, Mi S H. Agricultural sector carbon footprint accounting: a case of Zhejiang, China. Issues in Agricultural Economy, 2011; 32(11): 40-47, 111. (in Chinese)

[38] Chen X P, Cui Z L, Fan M S, Vitousek P, Zhao M, Ma W Q, et al. Producing more grain with lower environmental costs. Nature, 2014; 514(7523): 486-489.

[39] Hou P, Tao W H, Hao Z, Fan C D, Huang N. Greenhouse gas emission factors of Chinese power grids for organization and product carbon footprint. China Environmental Science, 2012; 32(6): 961-967. (in Chinese)

[40] Wang F J, Zhang M Y, Zhang H L, Chen F. Evaluation of tillage treatments on soil carbon sequestration in North China Plain. Journal of China Agricultural University, 2012; 17(4): 40-45. (in Chinese)

[41] Klenk I, Landquist B, de Imana O R. The product carbon footprint of EU beet sugar (Part II). Sugar Industry-Zuckerindustrie, 2012; 137(4): 213-221.

[42] Li J H, Yang S G, Zheng Z, Song H M, Meng Z. Anaerobic batch co-digestion of cornstalk and potato. Acta Energiae Solaris Sinica, 2008; 29(10): 1308-1312.

[43] Li K R. Land use change, net emission of greenhouse gases and carbon 
cycle in terrestrial ecosystems. Beijing: China Meteorological Press, 2002; 310p. (in Chinese)

[44] Zhu Y, Waqas MA, Li Ye, Zou X, Jiang D, Wilkes A, et al. Large-scale farming operations are win-win for grain production, soil carbon storage and mitigation of greenhouse gases. Journal of Cleaner Production, 2018; 72: $2143-2152$

[45] Li S T, Liu X Y, He P. Analyses on nutrient requirements in current agriculture production in China. Journal of Plant Nutrition and Fertilizer, 2017; 33(6): 1416-1432. (in Chinese)

[46] Wang G L. Quantitative analysis of reactive nitrogen losses and nitrogen use efficiency of three major grain crops in China. $\mathrm{PhD}$ dissertation. China Agricultural University, 2014; 121p.

[47] Li S T, Jin J Y. Characteristics of nutrient input/output and nutrient balance in different regions of China. Scientia Agricultura Sinica, 2011; 44(20): 4207-4229. (in Chinese)

[48] NDRC. Notice of General Office of the National Development and Reform Commission and Ministry of Agriculture and Rural Affairs on the final assessment of the comprehensive utilization plan of crop straw. Available: http://www.ndrc.gov.cn/zcfb/zcfbtz/201512/t20151216 767695.html Accessed on [2019-11-17]. (in Chinese)

[49] Climate Change Response Division of National Development and Reform Commission. Low carbon development and guidelines for the preparation of provincial greenhouse gas inventories Beijing, 2013. (in Chinese)

[50] Shi Z L, Jia T, Wang Y J, Wang J C, Sun R H, Wang F, et al. Comprehensive utilization status of crop straw and estimation of carbon from burning in China. Journal of China Agricultural Resources and Regional Planning, 2017; 38(9): 32-37. (in Chinese)

[51] Zheng L C, Zhang X D. Ecosystem positioning observation and research dataset in China (farmland ecosystem). Shenyang Station, Liaoning Province: 1998-2008. Beijing: China Agriculture Press, 2010. (in Chinese)

[52] Wang L, Song Q L, Feng Y J, Sun Y, Zeng X N, Lai Y C. Effect of applying nitrogenous fertilizer on decomposition of returned paddy straw. Jiangsu Agricultural Sciences, 2017; 45(11): 197-201. (in Chinese)

[53] $\mathrm{Hu} \mathrm{C} \mathrm{S}$, Cheng Y S. Ecosystem positioning observation and research dataset in China (farmland ecosystem): Luancheng Station, Hebei Province (1998-2008). Beijing: China Agriculture Press, 2010. (in Chinese)

[54] Niu W J. Physicochemical composition and energy potential of main crop straw and stalk. Beijing: China Agricultural University, 2015. (in Chinese)

[55] Ma Q L, Han L J, Huang G Q. Quantitative characterization of rape straw combustion and gas emissions using TG/DSC-FTIR-MS technology. Transactions of the CSAM, 2014; 45(S1): 196-201. (in Chinese)

[56] Han X Z, Wang S Y. Ecosystem positioning observation and research dataset in China (farmland ecosystem): Hailun Station, Heilongjiang Province (1998-2008). Beijing: China Agriculture Press, 2010. (in Chinese)

[57] $\mathrm{Hu} \mathrm{L}$. A preliminary evaluation of the carbon footprint and the effect of straw returning to the production of several vegetables. MS dissertation. Changsha: Hunan Agricultural University, 2016; 76p. (in Chinese)

[58] Han Z Y, Meng Y L, Xu J, Wu Y, Zhou Z G. Temporal and spatial difference in carbon footprint of regional farmland ecosystem--taking Jiangsu Province as a case. Journal of Agro-Environment Science, 2012; 31(5): 1034-1041. (in Chinese)

[59] Bryngeisson D, Wirsenius S, Hedenus F, Sonesson U. How can the EU climate targets be met? A combined analysis of technological and demand-side changes in food and agriculture. Food Policy, 2016; 59: $152-164$.

[60] Chen X H. Resource and environmental costs of cropping structure change in China. Beijing: China Agricultural University, 2018. (in Chinese)

[61] Zhang T, Feng Y, Li C, Ren G, Yang G. The carbon footprint analysis of straw biogas utilization of China in 2011. Journal of Northwest A\&F University (Natural Science Edition), 2014; 42(3): 124-130. (in Chinese)

[62] Zhang Z, Han Y, Qi Z, Chen P. Effect of water and nitrogen coupling on ch4 emission and rice yield in black soil paddy fields with straw returned to field. Transactions of the CSAM, 2020; 51(7): 254-262. (in Chinese)

[63] Zhang Z, Wang Z, Zhang Z, Wang X. Effects of different irrigations on carbon emission, water consumption and yield of paddy field in cold regions. Journal of Irrigation and Drainage, 2018; 37(11): 1-7. (in Chinese)

[64] Tian Z, Fan Y, Wang K, Zhong H, Sun L, Fan D, et al. Searching for "Win-Win" solutions for food-water-GHG emissions tradeoffs across irrigation regimes of paddy rice in China. Resources, Conservation and Recycling, 2021; 166: 105360. doi: 10.1016/j.resconrec.2020.105360.

[65] Ishfaq M, Farooq M, Zulfiqar U, Hussain S, Akbar N, Nawaz A, et al. Alternate wetting and drying: A water-saving and ecofriendly rice production system. Agricultural Water Management, 2020; 241: 106363. doi: 10.1016/j.agwat.2020.106363.

[66] Zheng Y, Wei G. Current status of water-saving irrigation in Heilongjiang Province and the development trend of information technology in irrigation areas. Hydro Science and Cold Zone Engineering, 2020; 3(2): 148-150

[67] Chu T, Wang D, Han L, Yang Z. Analysis and evaluation of farmland soil nutrient balance in Heilongjiang Land Reclamation Areas, China. Transactions of the CSAE, 2020; 36(15): 19-27. (in Chinese)

[68] Swaney D P, Howarth R W, Hong B. Nitrogen use efficiency and crop production: Patterns of regional variation in the United States, 1987-2012. Science of the Total Environment, 2018; 635: 498-511.

[69] Zhou X, Xin J, Shen X, Xu Y, Fu G, Liu X, et al. The extension of deep side fertilizing technology in rice production - Take Heilongjiang as an example. Chinese Agricultural Science Bulletin, 2021; 37(2): 140-146.

[70] Jiang Y, van Groenigen K J, Huang S, Hungate B A, van Kessel C, Hu S, et al. Higher yields and lower methane emissions with new rice cultivars. Global Change Biology, 2017; 23(11): 4728-4738

[71] Li C, Guo T, Wang Z, Zheng W, Zhao H, Zhang Z, et al. Evaluation and determination of yield evaluation indicators of soybean mainly cultivated varieties in the central and eastern of Heilongjiang Province. Crops, 2021; 2: 45-51. (in Chinese)

[72] Yan J, Chen X, Zou W, Zou S. Effects of long-term organic manure application on yield of soybean. Soybean Science, 2019; 38(6): 943-948. (in Chinese) 